\title{
DAMPAK PENCEMARAN LINGKUNGAN AKIBAT LIMBAH INDUSTRI PENGOLAHAN IKAN DI MUNCAR (Studi Kasus Kawasan Industri Pengolahan Ikan di Muncar - Banyuwangi)
}

\author{
Oleh : \\ Setiyono dan Satmoko Yudo
}

Peneliti di Pusat Teknologi Lingkungan, BPPT

\begin{abstract}
Muncar area is a regional fish producer. There, we can find big and small scale fish processing industries and even home industries. Those industry produce on the average 1,300 ton/day processed fish. Production activities caused environmental pollution, especially air, water and soil pollution. Source of this pollution are from transportation movement and developmnet of raw material, quality control activities to employee's activities (domestic waste). Right now the process of waste management is so little and people's understanding about wastewater treatment (IPAL) and waste management system is so limited. Almost all waste from this area is flowed away to the public canal. Flowing away waste directly without any process could increase environmental pollution around industrial location. This paper explains how big the potential waste water pollution, kind and charactestic of pollution from fish processing industries and doing waste management evaluation in fish processing indutries in Muncar. Italso shows sort of pollution effect as a result of disposing fish processing industry waste in Muncar.
\end{abstract}

Kata Kunci : Industri Pengolahan Ikan, Dampak Pencemaran Limbah Industri.

\section{PENDAHULUAN}

Upaya pengendalian pencemaran di Indonesia sampai saat ini masih mengalami banyak kendala. Sebagian dari penghasil bahan pencemar masih belum melakukan pengolahan terhadap limbahnya karena adanya berbagai kendala antara lain kurangnya kesadaran bahwa pengelolaan limbah merupakan investasi jangka panjang yang harus dilakukan, kurangnya informasi teknologi IPAL yang efektif dan efisien serta kurangnya sumber daya manusia yang menguasai teknologi IPAL.

Akhir-akhir ini kerisauan masyarakat akibat pencemaran lingkungan telah mencapai tingkat yang mencekam. Banyak ahli berdiskusi tentang hal tersebut, namun permasalahan masih terus berlangsung. Kerisauan akan makin bertambah jika penanganan permasalahan tidak kunjung selesai meskipun berbagai proyek penanggulangan telah menghabiskan dana milyaran rupiah. Hal-hal seperti ini akan menyulut ke persoalan sosial yang rumit antara penghasil limbah, masyarakat yang terkena dampak dan para pihak yang telah memberikan proyek penanggulangan, apalagi jika dana diambil dari dana masyarakat/ pemerintah.

Salah satu industri yang berkembang secara alami adalah industri pengolahan ikan di Kecamatan Muncar - Kabupaten Banyuwangi. Industri ini berkembang sejak jaman penjajahan
Belanda. Pada awalnya Industri ini merupakan industri kecil, tetapi saat ini sebagian dari industri ini saat ini telah berkembang menjadi industri besar yang berorientasi ekspor.

Karena sebagian besar industri yang ada di Muncar ini tumbuh secara alami, dengan modal usaha kecil, dan banyak dilakukan oleh masyarakat dengan tingkat pengetahuan tentang lingkungan yang masih kurang, maka adanya industri ini telah banyak menimbulkan dampak terhadap lingkungan. Persoalan di Muncar semakin komplek, akibat tingkat pemahaman tentang lingkungan dan sistem manajemen limbah oleh masyarakat maupun tingkat ketaatan terhadap hukum lingkungan yang masih kurang serta lemahnya penegakkan hukum lingkungan yang berlaku.

Pemerintah daerah bersama berbagai instansi pemerintah dari Propinsi dan Pusat telah membuat beberapa program untuk menanggulangi masalah limbah industri pengolahan ikan di Muncar. Salah satu program yang telah dilakukan adalah melakukan evaluasi lingkungan di kawasan Muncar.

\section{TUJUAN DAN SASARAN}

\section{Tujuan}

- Menghitung potensi pencemaran limbah cair dari industri pengolahan ikan. 
- Mengetahui jenis dan karakteristik limbah industri pengolahan ikan.

- Mengevaluasi pengelolaan limbah industri pengolahan ikan di Muncar.

- Mengetahui jenis dampak pencemaran akibat pembuangan limbah industri pengolahan ikan di Muncar.

- Mengevaluasi dampak pencemaran akibat pembuangan limbah industri pengolahan ikan di Muncar.

- Mencari solusi penanggulangan pencemaran lingkungan akibat pembuangan limbah.

\section{Sasaran}

Teridentifikasinya dampak pencemaran lingkungan akibat pembuangan limbah dan ditemukannya teknologi pengelolaan yang tepat.

\section{METODOLOGI}

Metodologi pelaksanaan kegiatan ini ada 4 tahap yaitu :

\section{Survai}

Kegiatan Survai dilaksanakan di wilayah Muncar-Banyuwangi, Jawa Timur dengan melakukan observasi lapangan dan pengambilan sampel limbah dan sampel air permukaan di sekitar lokasi untuk dianalisa laboratorium. Survai juga dilakukan untuk menghitung potensi timbulan limbah dan penyebarannya di kawasan Muncar.

\section{Pengumpulan Data}

Pengumpulan data dilakukukan dari berbagai instansi antara lain :

- Dinas lingkungan hidup kabupaten Banyuwangi yang mengelola lingkungan kawasan Muncar,

- Dinas perindustrian kabupaten Banyuwangi yang melakukan pembinaan dan pengawasan industri di Muncar,

- Kementerian Lingkungan Hidup Jakarta, yang telah melakukan pembinaan pengelolaan lingkungan di Muncar,

- Departemen. Perindustrian Pusat yang telah melakukan pembinaan terhadap industri di Muncar.

\section{Pengolahan Data dan Analisis}

Melakukan pengolahan data primer dan sekunder dan hasil analisa laboratorium yang telah diperoleh dengan bantuan perangkat lunak berbasis data dan statistik kemudian hasilnya dianalisa dan dibahas.

\section{HASIL YANG DIHARAPKAN}

Hasil yang diharapkan dari pekerjaan ini adalah sebagai berikut :

1. Diperolehnya data tentang jenis, jumlah timbulan limbah industri pengolahan ikan di Muncar.

2. Diketahuinya karakteristik limbah buangan dari setiap jenis industri yang ada.

3. Diperolehnya peta sebaran pembuangan limbah industri.

4. Diketahuinya beban pencemaran terhadap lingkungan di sekitar Muncar.

5. Diketahuinya kualitas lingkungan di sekitar industri.

6. Teridentifikasinya dampak lingkungan akibat pembuangan limbah industri.

7. Teridentifikasinya teknologi untuk penanggulangan limbah buangan industri.

\section{HASIL DAN PEMBAHASAN}

\subsection{Kapasitas Produksi Industri Pengolahan Ikan di Muncar}

\section{Industri Skala Besar :}

Dari hasil survai dan pedekatan penghitungan kapasitas produksi dari 69 industri pengolahan ikan skala besar dan menengah, maka rata-rata produksi perharinya adalah sebagai berikut :

- Industri pengalengan ikan = 145 ton/hari,

- Industri tepung ikan = 505 ton/hari,

- Industri cold storage = 210 ton/hari,

- Industri minyak ikan = 29 ton/hari,

- Produk ikan lainnya = 320 ton/hari. Total kapasitas $=1.209$ ton/hari.

Dari 69 perusahaan tersebut dipekerjakan karyawan sekitar 4.797 orang.

\section{Industri Skala Kecil / Rumah Tangga :}

Berdasarkan hasil survai dan pedekatan penghitungan kapasitas produksi dari 40 industri pengolahan ikan skala kecil/rumah tangga, maka rata-rata produksi per harinya adalah sebagai berikut :

- Industri tepung ikan = 80 ton/hari,

- Industri minyak ikan $=23.400$ lt/hari,

- Industri pemindangan ikan = 100 ton/hari,

Dengan melihat potensi produksi dan jumlah karyawan yang terlibat di usaha ini, maka potensi kegiatan industri pengolahan ikan ini merupakan suatu usaha yang sangat besar dan membutuhkan suatu perhatian khusus untuk 
melakukan pengelolaan agar dapat berjalan dengan baik dan meminimisasi dampak negatif yang mungkin dapat timbul.

\subsection{Jenis dan Jumlah Kegiatan Usaha Pengolahan Ikan di Muncar}

Ada beberapa jenis industri pengolahan ikan yang berkembang di Muncar antara lain : industri minyak ikan, industri pengalengan ikan, industri pemindangan ikan, industri tepung ikan dan industri pengolahan ikan lainnya telah tumbuh di wilayah ini.

Sampai dengan tahun 2007, di wilayah Muncar telah tercatat ada sekitar 67 industri pengolahan ikan skala besar dan 40 industri pengolahan ikan skala kecil/rumah tangga. Secara detail daftar industri besar dan kecil serta jenis usahanya dapat dilihat pada Tabel 1 sebagai berikut :

Tabel 1: Daftar Industri Besar Dan Kecil Serta Jenis Usahanya

\begin{tabular}{|c|c|c|c|c|}
\hline \multirow[b]{2}{*}{ Jenis Industri } & \multicolumn{2}{|c|}{$\begin{array}{c}\text { DKP. Kab. Banyuwangi, } \\
\text { Tahun 2005 }\end{array}$} & \multicolumn{2}{|c|}{$\begin{array}{l}\text { Hasil Survai Tim KLH, } \\
\text { BPPT, IPB, Tahun } 2007\end{array}$} \\
\hline & $\begin{array}{l}\text { Jumleh } \\
\text { (Unithi }\end{array}$ & $\begin{array}{l}\text { Produksi } \\
\text { (tonihari) }\end{array}$ & $\begin{array}{l}\text { Jumlah } \\
\text { (Unit) }\end{array}$ & $\begin{array}{l}\text { Produksi } \\
\text { [tonihani] }\end{array}$ \\
\hline \multicolumn{5}{|c|}{ IndustiBesar } \\
\hline -applrg|kig & 35 & $35-525$ & 27 & 515 \\
\hline 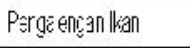 & $\bar{i}$ & 5.100 & 15 & 25 \\
\hline Cols Sorz]e & 3 & $1 \div 5-221$ & 27 & 2110 \\
\hline 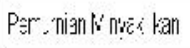 & $\bar{i}$ & 7.25 & 4 & 2,85 \\
\hline Laj--ai' & & & & 3iil \\
\hline \multicolumn{5}{|c|}{ Industikecil } \\
\hline Par no.angy & ill & $90-50$ & & \\
\hline Parga & $-i$ & $5-4 i$ & & \\
\hline Pettis, terasi & $\bar{i}$ & $125-100$ & & \\
\hline - spurgiken ‘k,ya: & 12 & $n \bar{e}$ & & \\
\hline kir ; & па & $n \bar{\varepsilon}$ & & \\
\hline
\end{tabular}

Sumber :

Laporan Pengelolaan Lingkungan Industri Pengolahan Ikan di Muncar. Kedeputian Bidang Pengendalian Pencemaran Lingkungan, KLH. 2007.

\subsection{Sebaran Industri Pengolahan Ikan di Muncar}

Sebaran industri pengolahan ikan di Muncar ini meliputi di 3 desa yaitu : Desa Tembokrejo, Kedungrejo dan Blambangan. Secara detail peta sebaran industri pengolahan ikan yang ada dapat dilihat pada lampiran
Gambar 1 : Peta Sebaran Industri Pengolahan Ikan di Muncar.

\subsection{Potensi Sumber Pencemaran/Sumber Limbah}

Kegiatan industri pengolahan ikan di Muncar kurang memperhatikan faktor-faktor pelestarian lingkungan secara maksimal. Banyak aktivitas kegiatan yang menghasilkan limbah dan belum ada upaya untuk penanggulangannya sehingga menjadikan beban lingkungan untuk menetralisasi semakin berat.

Dari hasil survai diketahui bahwa potensi sumber limbah kegiatan industri pengolahan ikan di Muncar mulai muncul sejak dari kegiatan pendaratan ikan, transportasi ikan, pencucian bahan baku, proses produksi, sampai sarana pengolahan limbah yang kurang berfungsi dengan baik.

\subsection{Potensi Jumlah Limbah Yang Dihasilkan}

Berdasarkan sumbernya, air limbah yang dihasilkan di kawasan industri pengolahan ikan ini dikelompokkan atas 2 jenis, yaitu:

1. Air limbah domestik, yaitu air limbah yang berasal dari kamar mandi, toilet, kantin, wastavel dan tempat wudu. Sesuai dengan aktivitasnya, maka sumber air limbah domestik ini dihasilkan oleh semua industri yang ada.

2. Air limbah produksi, berasal aktifitas produksi seperti pencucian komponenkomponen peralatan dan lantai ruang produksi. Sesuai dengan jenis kegiatannya/ industrinya dan aktivitas yang ada di setiap perusahaan, maka air limbah ini dapat dikelompokkan dalam beberapa kelompok dengan karakteristik yang berlainan, yaitu air limbah industri tepung ikan, air limbah industri minyak ikan, air limbah industri coold storage, dan air limbah industri pengalengan ikan.

Dalam proses produksi, air digunakan mulai dari pencucian/pembersihan bahan baku, pembersihan isi perut ikan, pemasakan, dan pembersihan lokasi pabrik. Karena sampai saat ini sistem monitoring/kontrol terhadap kebutuhan air di Muncar belum termonitor dengan baik, maka untuk menghitung jumlah pemakaiannya dilakukan pendekatan (asumsi) berdasarkan kebutuhan air maksimal sesuai Peraturan Menteri LH. No. 06 tahun 2007, tentang Baku Mutu Air Limbah Bagi Usaha dan/atau Kegiatan Pengolahan Hasil Perikanan.

Pendekatan/asumsi pemakaian sumber daya air untuk industri pengolahan ikan skala besar adalah sebagai berikut: 


\begin{tabular}{|l|l|c|}
\hline No. & \multicolumn{1}{|c|}{ Industri } & $\mathbf{M}^{\mathbf{3}}$ ton \\
\hline 1. & Pengalengan Ikan & 20 \\
\hline 2. & Tepung Ikan & 12 \\
\hline 3. & Cold Storage Ikan & 15 \\
\hline 4. & Minyak Ikan & 10 \\
\hline 5. & Pengolahan Ikan Lainnya & 15 \\
\hline 6. & Keperluan Domestik & 0,10 \\
\hline
\end{tabular}

Dengan menggunakan asumsi tersebut, maka jumlah kebutuhan air bersih untuk industri skala besar di Muncar rata-rata $14 \mathrm{~m}^{3}$ /ton produk. Dengan demikian maka kebutuhan air secara total adalah :

- Kebutuhan air produksi $=17.358,5 \mathrm{~m}^{3} /$ hari,

- Kebutuhan domestik $=474,7 \mathrm{~m}^{3} /$ hari.

Maka total kebutuhan air bersih adalah $17.833,2$ $\mathrm{m}^{3} /$ hari. Besarnya jumlah pemakaian air untuk kegiatan industri ini, berarti juga akan dihasilkan limbah cair yang sangat besar pula. Berdasarkan jumlah pemakaian air tesebut, maka jumlah limbah cair yang dihasilkan dapat mencapai $14.266 \mathrm{~m}^{3} /$ hari.

\subsection{Karakteristik Limbah Industri Pengolahan Ikan}

Ada tiga jenis kegiatan utama industri pengolahan ikan di Muncar. Masing-masing kegiatan tersebut mempunyai proses produksi yang berbeda, sehingga kuantitas dan kualitas limbah yang dibuang juga akan berbeda. Tiga jenis kegiatan utama tersebut adalah industri pengalengan ikan, industri cold storage dan industri minyak ikan, industri tepung ikan. Hasil analisa karakteristik limbah dari masing-masing industri tersebut adalah sebagai berikut :

Tabel 2 : Hasil Analisa Limbah Industri Cold Storage

\begin{tabular}{|l|l|}
\hline Jenis Industri & Cold Storage \\
\hline Waktu Pengujian & 18-April-07 s/d 01-Mei-07 \\
\hline $\begin{array}{l}\text { Tgl - jam } \\
\text { pengambilan }\end{array}$ & 17-April 07/12:20 \\
\hline Tgl - jam diterima & 18-April 07/16:30 \\
\hline $\begin{array}{l}\text { Titik } \\
\text { Pengambilan } \\
\text { sampel }\end{array}$ & $\begin{array}{l}\text { Effluent Industri Cold } \\
\text { Storage }\end{array}$ \\
\hline
\end{tabular}

\begin{tabular}{|l|l|l|l|l|}
\hline No. & PARAMETER & SATUAN & $\begin{array}{l}\text { BAKU } \\
\text { MUTU }\end{array}$ & $\begin{array}{l}\text { HASIL } \\
\text { UJI }\end{array}$ \\
\hline & I. FISIKA & & & \\
\hline
\end{tabular}

\begin{tabular}{|l|l|l|l|l|}
\hline 1 & Suhu & ${ }^{\circ} \mathrm{C}$ & - & 27,2 \\
\hline 2 & Total Suspended Solid & $\mathrm{mg} / \mathrm{L}$ & 100 & 98,5 \\
\hline & I. KIMIA & & & \\
\hline 1 & $\mathrm{pH}$ & - & $6-9$ & 7,66 \\
\hline 2 & Sulfida $\left(\mathrm{H}_{2} \mathrm{~S}\right)$ & $\mathrm{mg} / \mathrm{L}$ & - & 0,89 \\
\hline 3 & Khlorin Bebas $\left(\mathrm{Cl}_{2}\right)$ & $\mathrm{mg} / \mathrm{L}$ & 1 & 0,02 \\
\hline 4 & $\begin{array}{l}\text { Ammoniak Bebas } \\
\left(\mathrm{NH}_{3}-\mathrm{N}\right)\end{array}$ & $\mathrm{mg} / \mathrm{L}$ & 10 & 0,0038 \\
\hline 5 & BOD 5 & $\mathrm{mg} / \mathrm{L}$ & 100 & 46 \\
\hline 6 & COD & $\mathrm{mg} / \mathrm{L}$ & 200 & 100 \\
\hline 7 & Nitrat $\left(\mathrm{NO}_{3}-\mathrm{N}\right)$ & $\mathrm{mg} / \mathrm{L}$ & - & 1,03 \\
\hline 8 & Detergent & $\mathrm{mg} / \mathrm{L}$ & - & 0,76 \\
\hline 9 & Pospat $\left(\mathrm{PO}_{4}\right)$ & $\mathrm{mg} / \mathrm{L}$ & - & 0,75 \\
\hline 10 & Minyak $\mathrm{Lemak}$ & $\mathrm{mg} / \mathrm{L}$ & 15 & 0,02 \\
\hline
\end{tabular}

BML : Sesuai dengan Per. Men. LH. No. 06 tahun 2007, tentang "Baku Mutu Air Limbah Bagi Usaha dan/atau Kegiatan Pengolahan Hasil Perikanan".

Tabel 3. : Hasil Analisa Effluent Industri Tepung Ikan

\begin{tabular}{|l|l|}
\hline Jenis Industri & Tepung Ikan \\
\hline $\begin{array}{l}\text { Waktu } \\
\text { Pengujian }\end{array}$ & 18-April-07 s/d 01-Mei-07 \\
\hline $\begin{array}{l}\text { Tgl- waktu } \\
\text { pengambilan }\end{array}$ & 16-April 07/12:04 \\
\hline $\begin{array}{l}\text { Tgl- jam } \\
\text { diterima }\end{array}$ & 18-April 07/16:30 \\
\hline $\begin{array}{l}\text { Titik } \\
\text { Pengambilan } \\
\text { sampel }\end{array}$ & $\begin{array}{l}\text { Effluent Industri Tepung } \\
\text { Ikan }\end{array}$ \\
\hline
\end{tabular}

\begin{tabular}{|l|l|l|l|l|}
\hline NO & PARAMETER & SATUAN & $\begin{array}{l}\text { BAKU } \\
\text { MUTU }\end{array}$ & $\begin{array}{l}\text { HASIL } \\
\text { UJI }\end{array}$ \\
\hline & I. FISIKA & & & \\
\hline 1 & Suhu & ${ }^{\circ} \mathrm{C}$ & - & 29,5 \\
\hline 2 & Total Suspended Solid & $\mathrm{mg} / \mathrm{L}$ & 100 & 515 \\
\hline & I. KIMIA & & & \\
\hline 1 & pH & - & $6-9$ & 7,39 \\
\hline 2 & Sulfida $\left(\mathrm{H}_{2} \mathrm{~S}\right)$ & $\mathrm{mg} / \mathrm{L}$ & 1 & 1,52 \\
\hline 3 & Khlorin Bebas $\left(\mathrm{Cl}_{2}\right)$ & $\mathrm{mg} / \mathrm{L}$ & - & 0,01 \\
\hline 4 & $\begin{array}{l}\text { Ammoniak Bebas }\left(\mathrm{NH}_{3}-\right. \\
\text { N) }\end{array}$ & $\mathrm{mg} / \mathrm{L}$ & 5 & 0,0049 \\
\hline
\end{tabular}

\begin{tabular}{|l|l|l|l|l|}
\hline 5 & BOD $_{5}$ & $\mathrm{mg} / \mathrm{L}$ & 100 & 707 \\
\hline 6 & COD & $\mathrm{mg} / \mathrm{L}$ & 300 & 1700 \\
\hline 7 & Nitrat $\left(\mathrm{NO}_{3}-\mathrm{N}\right)$ & $\mathrm{mg} / \mathrm{L}$ & - & 2,35 \\
\hline 8 & Detergent & $\mathrm{mg} / \mathrm{L}$ & - & 0,25 \\
\hline 9 & Pospat $\left(\mathrm{PO}_{4}\right)$ & $\mathrm{mg} / \mathrm{L}$ & - & 3,91 \\
\hline 10 & Minyak Lemak & $\mathrm{mg} / \mathrm{L}$ & 15 & 8,54 \\
\hline
\end{tabular}


BML : Sesuai dengan Per. Men. LH. No. 06 tahun 2007, tentang "Baku Mutu Air Limbah Bagi Usaha dan/atau Kegiatan Pengolahan Hasil Perikanan".

Tabel 4. : Hasil Analisa Limbah Industri Pengalengan Ikan

\begin{tabular}{|l|l|}
\hline Jenis Industri & Pengalengan Ikan (Tuna) \\
\hline Waktu Pengujian & 18-April-07 s/d 01-Mei-07 \\
\hline $\begin{array}{l}\text { Tgl - waktu } \\
\text { pengambilan }\end{array}$ & 16-April 07/13:02 \\
\hline Tgl- jam diterima & 18-April 07/16:30 \\
\hline $\begin{array}{l}\text { Titik Pengambilan } \\
\text { sampel }\end{array}$ & $\begin{array}{l}\text { Effluent Industri Pe- } \\
\text { ngalengan Ikan (Tuna) }\end{array}$ \\
\hline
\end{tabular}

\begin{tabular}{|l|l|l|l|l|}
\hline NO. & PARAMETER & SATUAN & $\begin{array}{l}\text { BAKU } \\
\text { MUTU }\end{array}$ & $\begin{array}{l}\text { HASIL } \\
\text { UJI }\end{array}$ \\
\hline & I. FISIKA & & & \\
\hline 1 & Suhu & ${ }^{\circ} \mathrm{C}$ & - & 33,9 \\
\hline & $\begin{array}{l}\text { Total } \\
\text { Suspended } \\
\text { Solid }\end{array}$ & $\mathrm{mg} / \mathrm{L}$ & 100 & 637,5 \\
\hline & I. KIMIA & & & \\
\hline 1 & pH & - & $6-9$ & 7,2 \\
\hline 2 & Sulfida $\left(\mathrm{H}_{2} \mathrm{~S}\right)$ & $\mathrm{mg} / \mathrm{L}$ & 1 & 0,47 \\
\hline 3 & $\begin{array}{l}\text { Khlorin Bebas } \\
\text { (Cl})\end{array}$ & $\mathrm{mg} / \mathrm{L}$ & 1 & 0,08 \\
\hline 4 & $\begin{array}{l}\text { Ammoniak } \\
\text { Bebas }\left(\mathrm{NH}_{3}-\mathrm{N}\right)\end{array}$ & $\mathrm{mg} / \mathrm{L}$ & 5 & 0,0056 \\
\hline 5 & BOD & $\mathrm{mg} / \mathrm{L}$ & 75 & 689 \\
\hline 6 & COD & $\mathrm{mg} / \mathrm{L}$ & 150 & 1500 \\
\hline 7 & Nitrat $\left(\mathrm{NO}_{3}-\mathrm{N}\right)$ & $\mathrm{mg} / \mathrm{L}$ & - & 4,09 \\
\hline 8 & Detergent & $\mathrm{mg} / \mathrm{L}$ & - & 0,04 \\
\hline 9 & Pospat $\left(\mathrm{PO}_{4}\right)$ & $\mathrm{mg} / \mathrm{L}$ & - & 4,17 \\
\hline 10 & Minyak Lemak & $\mathrm{mg} / \mathrm{L}$ & 15 & 6,54 \\
\hline
\end{tabular}

BML : Sesuai dengan Per. Men. LH. No. 06 tahun 2007, tentang "Baku Mutu Air Limbah Bagi Usaha dan/atau Kegiatan Pengolahan Hasil Perikanan".

\subsection{Pengelolaan Limbah Industri di Muncar}

Pengelolaan limbah industri di Muncar belum dilakukan secara maksimal. Black water limbah domestik dikelola dalam septik tank, grey water dibuang langsung ke saluran umum, sedangkan sebagian limbah dari proses produksi hanya dilakukan pengendapan sederhana dan sebagian lagi belum dikelola sama sekali (langsung dibuang ke saluran umum). Beberapa perusahaan pernah mencoba membangun instalasi pengolahan limbah, namun tidak ada yang dapat berfungsi dengan baik sehingga unit pengolahan ini tidak difungsikan lagi.
Tumbuhnya industri pengolahan ikan di Muncar tidak dipersiapkan secara khusus, sehingga keberadaannya menyebar tidak teratur di tiga desa yaitu desa Tembokrejo, Kedungrejo dan Blambangan. Dengan ketidak teraturan lokasi industri ini, maka akan menyulitkan dalam mengelola limbah yang ada secara bersama sehingga sampai saat ini belum ada sistem pengelolaan limbah dalam skala kawasan.

\subsection{Dampak Dari Pembuangan Limbah}

Kegiatan industri di Muncar telah menimbulkan perubahan terhadap kondisi lingkungan di sekitarnya. Perubahan yang terjadi dapat bersifat positif dan bersifat negatif. Perubahan positif seperti terbukanya lapangan kerja baru, peningkatan kesejahteraan masyarakat, meningkatnya pendapatan daerah, berkembang-nya wilayah kota dan lain-lain harus dijaga dan ditingkatkan agar dapat memberikan manfaat yang sebesar-besarnya. Sedangkan perubahan yang bersifat negatif seperti adanya pencemaran terhadap lingkungan, meningkatnya kebutuhan lahan yang kurang terkendali dan lainlain harus dikendalikan agar tidak menimbulkan kerugian.

Dampak dari kegiatan industri di Muncar yang paling besar terlihat di lingkungan perairan. Sampai saat ini telah terjadi beberapa dampak akibat pencemaran air ini, antara lain :

- Dampak terhadap kualitas air permukaan dan air tanah.

- Dampak terhadap kehidupan biota air.

- Dampak terhadap kesehatan.

- Dampak terhadap estetika lingkungan.

- Dampak terhadap udara (kebauan) dll.

\subsubsection{Dampak terhadap estetika lingkungan}

Semakin banyaknya jumlah limbah yang masuk ke lingkungan tanpa pengolahan menyebabkan semakin berat nya beban lingkungan untuk menampung dan melakukan degradasi (self purification) terhadap limbah tersebut. Jika kemampuan lingkungan penerima limbah sudah terlampaui, maka akan mengakibatkan pencemaran dan terjadi akumulasi materi di lingkungan bersangkutan. Penumpukan materi yang tak terkendali akan menimbulkan berbagai dampak seperti bau menyengat, pemandangan yang kotor dan menimbulkan masalah estetika lain yang tidak diharapkan. Gambar 1. s/d 3. menunjukkan kondisi lingkungan yang secara estetika kurang baik. Kondisi jalan yang kotor, saluran drainase pembuangan limbah yang tampak kotor, penuh dengan belatung dan tumpukkan limbah padat yang diletakkan di pinggir saluran sehingga 
menyebabkan bau busuk yang sangat menyengat dan pemandangan yang kotor.

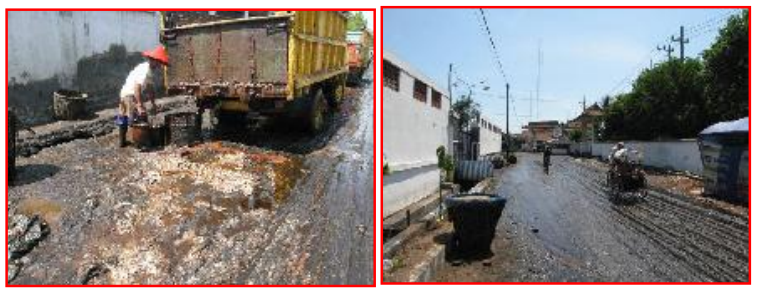

Gambar 1. : Kondisi jalanan yang becek akibat sistem dan alat tranportasi yang kurang baik.
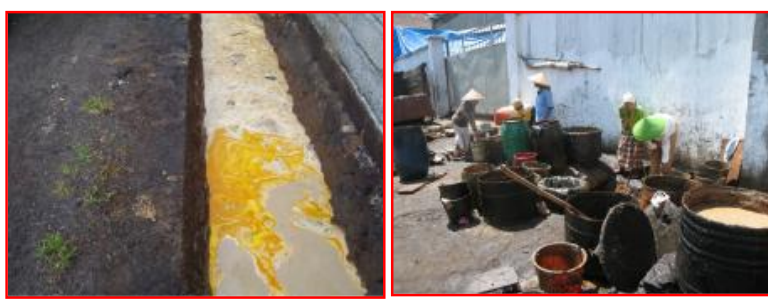

Gambar 2. : Kondisi kondisi saluran yang penuh dengan minyak dan aktivitas masyarakat pengais minyak.
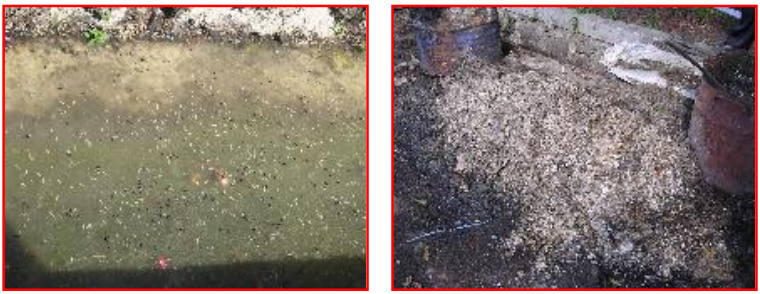

Gambar 3. : Saluran Air Yang Sangat Kotor Penuh Dengan Belatung Dan Tumpukkan Limbah Padat Di Sepanjang Jalan.

\subsubsection{Dampak Terhadap Kondisi Sosial Ekonomi Masyarakat}

Ada gula ada semut, begitu peribahasa mengatakan. Seperti hal-nya peribahasa tersebut, meskipun limbah merupakan bahan buangan yang dianggap sudah kurang efektif dan kurang layak untuk dimanfaatkan kembali oleh perusahaan, namun ternyata banyak masyarakat yang jeli melihat bahwa di dalam buangan tersebut masih banyak mengandung minyak dan bahan padat yang masih dapat dimanfaatkan kembali. Kandungan minyak dan padatan tersebut, meskipun jumlahnya sudah sangat minim tetapi ternyata masih dapat dikais dan dikumpulkan serta dimanfaatkan untuk memproduksi minyak ikan dan padatananya dapat untuk digunakan sebagai bahan pembuatan tepung ikan. Dengan adanya potensi untuk pengambilan kandungan minyak dan padatan tersebut, mengundang aktivitas beberapa masyarakat untuk melakukan kegiatan pengambilan minyak dan padatan tersebut.

Aktivitas masyarakat pengais minyak di sepanjang saluran ini menimbulkan kegiatan/aktivitas yang membuat pemandangan kurang indah, tetapi dari sisi lain mereka membantu mengurangi beban lingkungan untuk mendegradasi polutan yang ada di dalam limbah seperti halnya para pemulung sampah di TPA. Diantara para pengais limbah ini, beberapa diantaranya telah menjadikannya sebagai sumber kehidupan, sehingga kondisi sosial ekonominya tergantung dari kegiatan ini.
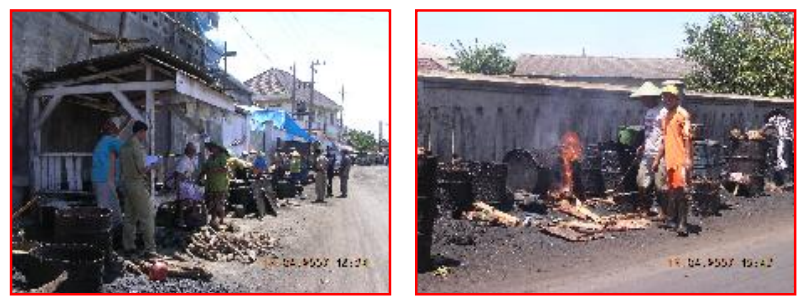

Gambar 4. : Aktivitas Masyarakat mengais Minyak dari Limbah di Sepanjang Jalan.
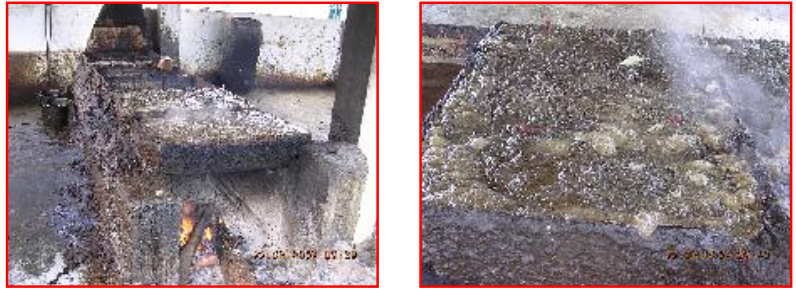

Gambar 5. : Cara Pengolahan Padatan Hasil Mengais Dari Limbah Yang Kurang Sehat.
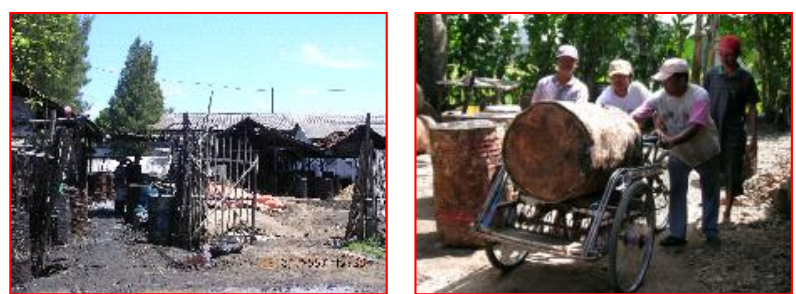

Gambar 6. : Sebagian Masyarakat Menjadikan Kegiatan Mengais Minyak Dan Padatan dari Limbah Sebagai Sumber Ekonomi.

\subsubsection{Dampak Terhadap Kualitas Air Permukaan}

Dari hasil survei dan analisa kualitas air sungai dan air laut di pantai di wilayah Muncar telah menunjukkan bukti bahwa kualitasnya telah bibawah standar kualitas air permukaan. Hal ini menunjukkan bahwa telah ada pembuangan limbah yang jumlahnya di atas daya tampung lingkungan penerima, sehingga mengakibatkan menurunnya kualitas air yang ada. Gambar 7 . menunjukkan kondisi kali mati di Muncar dan 
kondisi pantai di Muncar yang terlihat kotor, hitam dan banyak endapan/padatan hasil pembusukkan bahan organik buangan dari lingkungan sekitarnya. Gambar 9. menunjukkan peta pengambilan sampel air untuk dianalisa di laboratorium. Tabel 5 s.d. 9. menunjukkan hasil analisa kualitas air di kali dan pantai di Muncar yang menunjukkan bahwa kondisi telah tercemar.
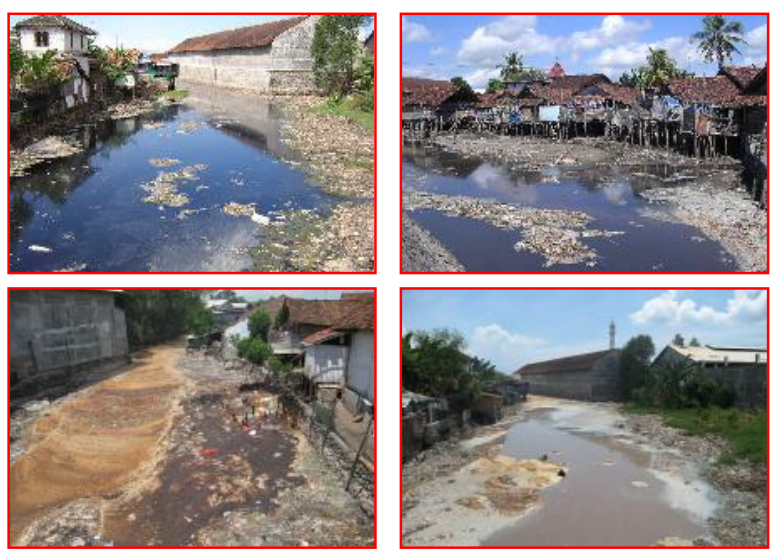

Gambar 7. : Foto Kondisi Kali Mati Pada Bulan Agustus 2006.
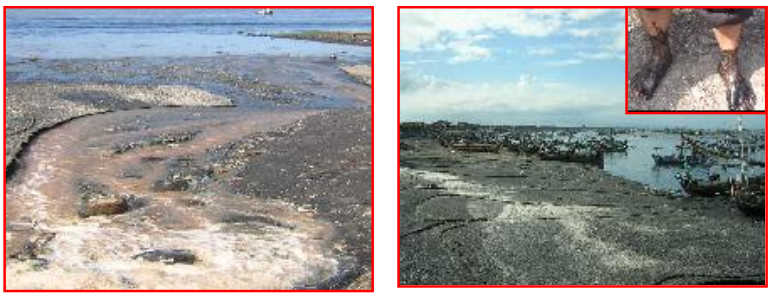

Gambar 8. : Foto Kondisi Pantai Di Muncar Pada Bulan Agustus 2006.

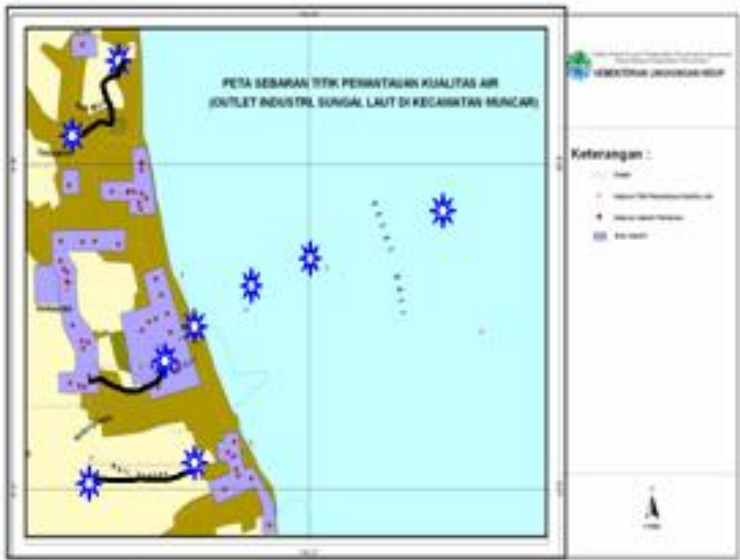

Gambar 9. : Peta Sebaran Titik Pemantauan Kualitas Air

Di bawah ini adalah hasil analisa kualitas air di beberapa sungai yang ada di daerah Muncar :

Tabel 5. : Hasil Analisa Air Muara Kali Mati

\begin{tabular}{|l|l|}
\hline Nama Sungai & KALI MATI \\
\hline Kelas & II \\
\hline
\end{tabular}

\begin{tabular}{|l|l|}
\hline Jenis Sampel & Air Badan Sungai \\
\hline Waktu Pengujian & 18-April-07 s/d 01-Mei-07 \\
\hline $\begin{array}{l}\text { Tgl - waktu } \\
\text { pengambilan }\end{array}$ & 17-April 07/16:35 \\
\hline Tgl - jam diterima & 18-April 07/16:30 \\
\hline $\begin{array}{l}\text { Titik Pengambilan } \\
\text { sampel }\end{array}$ & Muara Kali Mati \\
\hline
\end{tabular}

\begin{tabular}{|l|l|l|l|l|}
\hline NO & PARAMETER & SATUAN & $\begin{array}{l}\text { BAKU } \\
\text { MUTU }\end{array}$ & $\begin{array}{l}\text { HASIL } \\
\text { UJI }\end{array}$ \\
\hline & I. FISIKA & & & \\
\hline 1 & Suhu $\left.{ }^{*}\right)$ & ${ }^{\circ} \mathrm{C}$ & - & 31,4 \\
\hline 2 & Total Suspended Solid & $\mathrm{mg} / \mathrm{L}$ & 50 & 683 \\
\hline & I. KIMIA & & & \\
\hline 1 & $\left.\mathrm{pH}^{*}\right)$ & - & $6-9$ & 6,65 \\
\hline 2 & Sulfida $\left(\mathrm{H}_{2} \mathrm{~S}\right)$ & $\mathrm{mg} / \mathrm{L}$ & 0,002 & 7,04 \\
\hline 3 & Khlorin Bebas $\left(\mathrm{Cl}_{2}\right)$ & $\mathrm{mg} / \mathrm{L}$ & 0,03 & $\mathrm{Tt}$ \\
\hline 4 & Ammoniak Bebas $\left(\mathrm{NH}_{3}{ }^{-}\right.$ & $\mathrm{mg} / \mathrm{L}$ & - & 0,0017 \\
\hline 5 & Nitrat $\left(\mathrm{NO}_{3}-\mathrm{N}\right)$ & $\mathrm{mg} / \mathrm{L}$ & 10 & 2,7 \\
\hline 6 & BOD & $\mathrm{mg} / \mathrm{L}$ & 3 & 624 \\
\hline 7 & COD & $\mathrm{mg} / \mathrm{L}$ & 25 & 1.300 \\
\hline 8 & Minyak $\mathrm{Lemak}$ & $\mathrm{mg} / \mathrm{L}$ & 1 & 8,32 \\
\hline 9 & Detergent & $\mathrm{mg} / \mathrm{L}$ & 0,2 & 0,16 \\
\hline 10 & Pospat $\left(\mathrm{PO}_{4}\right)$ & $\mathrm{mg} / \mathrm{L}$ & 0,2 & 2,01 \\
\hline
\end{tabular}

BML : Sesuai dengan PPRI No. 82 Tahun 2001 tentang "Pengelolaan Kualitas Air dan Pengendalian Pencemaran Air".

Tabel 6 : Hasil Analisa Air Hulu dan Hilir Kali Tratas

\begin{tabular}{|l|l|}
\hline Nama Sungai & KALI TRATAS \\
\hline Kelas & II \\
\hline Jenis Sampel & Air Badan Sungai \\
\hline $\begin{array}{l}\text { Tgl - waktu } \\
\text { pengambilan }\end{array}$ & $17-$ April 07 \\
\hline $\begin{array}{l}\text { Tgl- jam } \\
\text { diterima }\end{array}$ & 18-April 07 \\
\hline $\begin{array}{l}\text { Waktu } \\
\text { Pengujian }\end{array}$ & 18-April-07 s/d 01-Mei-07 \\
\hline $\begin{array}{l}\text { Titik } \\
\text { Pengambilan } \\
\text { sampel }\end{array}$ & $\begin{array}{l}\text { Hulu (Tengah) dan Hilir } \\
\text { (Muara) Kali Tratas }\end{array}$ \\
\hline
\end{tabular}

\begin{tabular}{|c|c|c|c|c|c|}
\hline \multirow{2}{*}{ No. } & \multirow{2}{*}{ PARAMETER } & \multirow{2}{*}{ SATUAN } & \multirow{2}{*}{$\begin{array}{l}\text { BAKU } \\
\text { MUTU }\end{array}$} & \multicolumn{2}{|c|}{ HASIL UJI } \\
\hline & & & & Hulu & Hilir \\
\hline & I. FISIKA & & & & \\
\hline 1 & Suhu *) & ${ }^{\circ} \mathrm{C}$ & - & 29 & 29,6 \\
\hline \multirow[t]{2}{*}{2} & $\begin{array}{l}\text { Total } \\
\text { Suspended } \\
\text { Solid }\end{array}$ & $\mathrm{mg} / \mathrm{L}$ & 50 & 91 & 113,5 \\
\hline & I. KIMIA & & & & \\
\hline 1 & $\left.\mathrm{pH}^{*}\right)$ & - & $6-9$ & 6,89 & 6,8 \\
\hline 2 & Sulfida $\left(\mathrm{H}_{2} \mathrm{~S}\right)$ & $\mathrm{mg} / \mathrm{L}$ & 0,002 & 0,78 & 0,55 \\
\hline
\end{tabular}




\begin{tabular}{|l|l|l|l|l|l|}
\hline 3 & $\begin{array}{l}\text { Khlorin Bebas } \\
(\mathrm{Cl} / 2)\end{array}$ & $\mathrm{mg} / \mathrm{L}$ & 0,03 & 0,01 & 0,01 \\
\hline 4 & $\begin{array}{l}\text { Ammoniak } \\
\text { Bebas }\left(\mathrm{NH}_{3}-\mathrm{N}\right)\end{array}$ & $\mathrm{mg} / \mathrm{L}$ & - & 0,0013 & 0,003 \\
\hline 5 & Nitrat $\left(\mathrm{NO}_{3}-\mathrm{N}\right)$ & $\mathrm{mg} / \mathrm{L}$ & 10 & 2,46 & 2,38 \\
\hline 6 & BOD $_{5}$ & $\mathrm{mg} / \mathrm{L}$ & 3 & 8 & 601 \\
\hline 7 & COD & $\mathrm{mg} / \mathrm{L}$ & 25 & 20 & 1.300 \\
\hline 8 & Minyak Lemak & $\mathrm{mg} / \mathrm{L}$ & 1 & 0,01 & 0,006 \\
\hline 9 & Detergent & $\mathrm{mg} / \mathrm{L}$ & 0,2 & 0,01 & 0,11 \\
\hline 10 & Pospat $\left(\mathrm{PO}_{4}\right)$ & $\mathrm{mg} / \mathrm{L}$ & 0,2 & 0,38 & 0,5 \\
\hline
\end{tabular}

BML : Sesuai dengan PPRI No. 82 Tahun 2001 tentang "Pengelolaan Kualitas Air dan Pengendalian Pencemaran Air".

Tabel 7. : Hasil Analisa Air Hulu \& Hilir Kali Moro

\begin{tabular}{|l|l|}
\hline Nama Sungai & KALI MORO \\
\hline Kelas & II \\
\hline Jenis Sampel & Air Badan Sungai \\
\hline $\begin{array}{l}\text { Tgl - waktu } \\
\text { pengambilan }\end{array}$ & $17-$ April 07 \\
\hline Tgl - jam diterima & $18-$ April 07 \\
\hline Waktu Pengujian & $18-$ April-07 s/d 01-Mei-07 \\
\hline $\begin{array}{l}\text { Titik } \\
\text { Pengambilan } \\
\text { sampel }\end{array}$ & Hulu \& Hilir Kali Moro \\
\hline
\end{tabular}

\begin{tabular}{|c|c|c|c|c|c|}
\hline \multirow{2}{*}{ NO. } & \multirow{2}{*}{ PARAMETER } & \multirow{2}{*}{ SATUAN } & \multirow{2}{*}{$\begin{array}{l}\text { BAKU } \\
\text { MUTU }\end{array}$} & \multicolumn{2}{|c|}{ HASIL UJI } \\
\hline & & & & Hulu & Hilir \\
\hline & I. FISIKA & & & & \\
\hline 1 & Suhu *) & ${ }^{\circ} \mathrm{C}$ & - & 29,6 & 29,3 \\
\hline 2 & $\begin{array}{l}\text { Total Suspended } \\
\text { Solid }\end{array}$ & $\mathrm{mg} / \mathrm{L}$ & 50 & 150 & 145,5 \\
\hline & I. KIMIA & & & & \\
\hline 1 & $\left.\mathrm{pH}^{*}\right)$ & - & $6-9$ & 6,92 & 6,83 \\
\hline 2 & Sulfida $\left(\mathrm{H}_{2} \mathrm{~S}\right)$ & $\mathrm{mg} / \mathrm{L}$ & 0,002 & 0,1 & 0,09 \\
\hline 3 & $\begin{array}{l}\text { Khlorin Bebas } \\
\left(\mathrm{Cl}_{2}\right)\end{array}$ & $\mathrm{mg} / \mathrm{L}$ & 0,03 & 0,01 & $\mathrm{tt}$ \\
\hline 4 & $\begin{array}{l}\text { Ammoniak Bebas } \\
\left(\mathrm{NH}_{3}-\mathrm{N}\right)\end{array}$ & $\mathrm{mg} / \mathrm{L}$ & - & 0,001 & 0,0007 \\
\hline 5 & Nitrat $\left(\mathrm{NO}_{3}-\mathrm{N}\right)$ & $\mathrm{mg} / \mathrm{L}$ & 10 & 1,38 & 3,62 \\
\hline 6 & $\mathrm{BOD}_{5}$ & $\mathrm{mg} / \mathrm{L}$ & 3 & 12 & 13 \\
\hline 7 & COD & $\mathrm{mg} / \mathrm{L}$ & 25 & 28 & 30 \\
\hline 8 & Minyak Lemak & $\mathrm{mg} / \mathrm{L}$ & 1 & 0,009 & 0,98 \\
\hline 9 & Detergent & $\mathrm{mg} / \mathrm{L}$ & 0,2 & 0,001 & $\mathrm{tt}$ \\
\hline 10 & Pospat $\left(\mathrm{PO}_{4}\right)$ & $\mathrm{mg} / \mathrm{L}$ & 0,2 & 1,09 & 0,08 \\
\hline
\end{tabular}

BML : Sesuai dengan PPRI No. 82 Tahun 2001 tentang "Pengelolaan Kualitas Air dan Pengendalian Pencemaran Air".

Tabel 8. : Hasil Analisa Air Laut 25 m, 300 m. dan 350 dari Pantai Muncar

\begin{tabular}{|l|l|}
\hline $\begin{array}{l}\text { Lokasi/titik } \\
\text { Pengambilan }\end{array}$ & $\begin{array}{l}25 \text { meter, 300 meter dan } \\
350 \text { meter dari Pantai } \\
\text { Muncar }\end{array}$ \\
\hline Jenis Sampel & Air Laut \\
\hline
\end{tabular}

\begin{tabular}{|l|l|}
\hline $\begin{array}{l}\text { Waktu } \\
\text { Pengujian }\end{array}$ & 18-April-07 s/d 01-Mei-07 \\
\hline $\begin{array}{l}\text { Tgl - waktu } \\
\text { pengambilan }\end{array}$ & 17-April 07/13:48 \\
\hline $\begin{array}{l}\text { Tgl - jam } \\
\text { diterima }\end{array}$ & 18-April 07/16:30 \\
\hline
\end{tabular}

\begin{tabular}{|c|c|c|c|c|c|}
\hline \multirow[t]{2}{*}{ PARAMETER } & \multirow[t]{2}{*}{ SAT } & \multirow{2}{*}{$\begin{array}{l}\text { BAKU } \\
\text { MUTU }\end{array}$} & \multicolumn{3}{|c|}{$\begin{array}{l}\text { HASIL UJI } \\
\text { (Jarak dari garis pantai) }\end{array}$} \\
\hline & & & $25 \mathrm{~m}$ & $300 \mathrm{~m}$ & $350 \mathrm{~m}$ \\
\hline \multicolumn{6}{|l|}{ I. FISIKA } \\
\hline Suhu *) & ${ }^{\circ} \mathrm{C}$ & - & 34 & 31 & 32 \\
\hline $\begin{array}{l}\text { Total } \\
\text { Suspended } \\
\text { Solid } \\
\end{array}$ & $\mathrm{mg} / \mathrm{L}$ & 20 & 324,5 & 114 & 66,6 \\
\hline \multicolumn{6}{|l|}{ I. KIMIA } \\
\hline $\left.\mathrm{pH}^{*}\right)$ & - & - & 7,21 & 7,91 & 8,33 \\
\hline Sulfida $\left(\mathrm{H}_{2} \mathrm{~S}\right)$ & $\mathrm{mg} / \mathrm{L}$ & 0,01 & 7,65 & 0,45 & 0,57 \\
\hline $\begin{array}{l}\text { Khlorin Bebas } \\
\left(\mathrm{Cl}_{2}\right)\end{array}$ & $\mathrm{mg} / \mathrm{L}$ & - & 0,01 & 0,01 & $\mathrm{tt}$ \\
\hline $\begin{array}{l}\text { Ammoniak } \\
\text { Bebas }\left(\mathrm{NH}_{3}-\mathrm{N}\right)\end{array}$ & $\mathrm{mg} / \mathrm{L}$ & 0,3 & 0,0089 & 0,0065 & 0,0362 \\
\hline Nitrat $\left(\mathrm{NO}_{3}-\mathrm{N}\right)$ & $\mathrm{mg} / \mathrm{L}$ & 0,008 & 1,32 & 2,09 & 0,38 \\
\hline $\mathrm{BOD}_{5}$ & $\mathrm{mg} / \mathrm{L}$ & 20 & 360 & 57 & 12 \\
\hline COD & $\mathrm{mg} / \mathrm{L}$ & - & 850 & 120 & 30 \\
\hline Minyak Lemak & $\mathrm{mg} / \mathrm{L}$ & 1 & 0,08 & 0,03 & 0,02 \\
\hline Detergent & $\mathrm{mg} / \mathrm{L}$ & 1 & 0,07 & 0,12 & 0,24 \\
\hline Pospat $\left(\mathrm{PO}_{4}\right)$ & $\mathrm{mg} / \mathrm{L}$ & 0,015 & 0,17 & 0,08 & 0,05 \\
\hline
\end{tabular}

BML : Sesuai dengan Kep. Men LH No. 51 Tahun 2004 tentang Baku Mutu Air Laut untuk Biota Laut

\subsubsection{Dampak Terhadap Kehidupan Biota Air}

Dengan banyaknya zat pencemar yang ada di dalam air limbah, maka akan menyebabkan menurunnya kadar oksigen yang terlarut di dalam air limbah tersebut. Dengan demikian akan menyebabkan kehidupan yang ada di dalam perairan yang membutuhkan oksigen akan terganggu, dan mengurangi perkembangannya. Selain disebabkan karena kurangnya oksigen, kematian kehidupan di dalam air dapat juga disebabkan oleh adanya zat beracun. Selain kematian ikan-ikan, dampak lainnya adalah kerusakan pada tanaman/ tumbuhan air. Dari pengamatan selama survai di sepanjang aliran kali mati saat ini sudah jarang sekali ditemukan adanya ikan atau biota lainnya di kali tersebut. Hal ini juga dikuatkan oleh informasi dari masyarakat di sekitar sungai.

\subsubsection{Dampak Terhadap Kesehatan}

Pengaruh langsung terhadap kesehatan, banyak disebabkan oleh kualitas air bersih yang dimanfaatkan untuk memenuhi kebutuhan seharihari, mengingat sifat air yang mudah sekali terkontaminasi oleh berbagai mikro organisme 
dan mudah sekali melarutkan berbagai materi. Dengan kondisi sifat yang demikian air mudah sekali berfungsi sebagai media penyalur ataupun penyebar penyakit.

Peran air sebagai pembawa penyakit menular bermacam-macam, antara lain:

- air sebagai media untuk hidup mikroba patogen;

- air sebagai sarang insekta penyebar penyakit;

- jumlah air bersih yang tersedia tak cukup, sehingga manusia bersangkutan tak dapat membersihkan dirinya, atau;

- air sebagai media untuk hidup vektor penyebar penyakit.

Ada beberapa penyakit yang masuk dalam katagori water-borne diseases, atau penyakitpenyakit yang dibawa oleh air, yang masih banyak dijumpai di berbagai daerah seperti terlihat dalam Tabel 4.10. di bawah. Penyakitpenyakit ini hanya dapat menyebar apabila mikroba penyebabnya dapat masuk ke dalam sumber air yang dipakai masyarakat untuk memenuhi kebutuhannya sehari-hari. Sedangkan jenis mikroba yang dapat menyebar lewat air ada cukup banyak, antara lain, bakteri, protozoa dan metazoa.

Tabel 9. Beberapa penyakit Bawaan Air dan Agennya

\begin{tabular}{|c|c|}
\hline Agen & Penyakit \\
\hline $\begin{array}{l}\text { Virus: } \\
\text { Rotavirus } \\
\text { Virus Hepatitis A } \\
\text { Virus Poliomyelitis }\end{array}$ & $\begin{array}{l}\text { Diare pada anak } \\
\text { Hepatitis A } \\
\text { Polio (myelitis anterior } \\
\text { acuta) }\end{array}$ \\
\hline $\begin{array}{l}\text { Bakteri: } \\
\text { Vibrio cholerae Escherichia } \\
\text { coli Enteropatogenik } \\
\text { Salmonella typhi Salmonella } \\
\text { paratyphi Shigella } \\
\text { dysenteriae Protozoa: } \\
\text { Entamuba histolytica } \\
\text { Balantidia coli }\end{array}$ & $\begin{array}{l}\text { Cholera Diare/Dysenterie } \\
\text { Typhus abdominalis } \\
\text { Paratyphus } \\
\text { Dysenterie } \\
\text { Dysentrie amoeba } \\
\text { Balantidiasis }\end{array}$ \\
\hline Giarda lamblia & Giardiasis \\
\hline $\begin{array}{l}\text { Metazoa: } \\
\text { Ascaris lumbricoides } \\
\text { Clonorchis sinensis } \\
\text { Diphyllobothrium latum } \\
\text { Taenia saginata/solium } \\
\text { Schistosoma }\end{array}$ & $\begin{array}{l}\text { Ascariasis } \\
\text { Clonorchiasis } \\
\text { Diphylobothriasis } \\
\text { Taeniasis } \\
\text { Schistosomiasis }\end{array}$ \\
\hline
\end{tabular}

Masuknya berbagai polutan dari sumber pencemar ke manusia pada umumnya tidak terjadi secara langsung, tetapi lebih banyak melalui media jaring-jaring rantai makanan. Jika hal ini sudah terjadi, untuk mengatasinya memerlukan biaya yang sangat besar, waktu yang lama dan metode sulit untuk dilakukan dan pada umumnya dimulai dengan memutus rantai dari sumbernya. Secara detail gambaran perjalanan polutan limbah sampai ke manusia ini dapat dilihat seperti pada Gambar 10. di bawah ini.

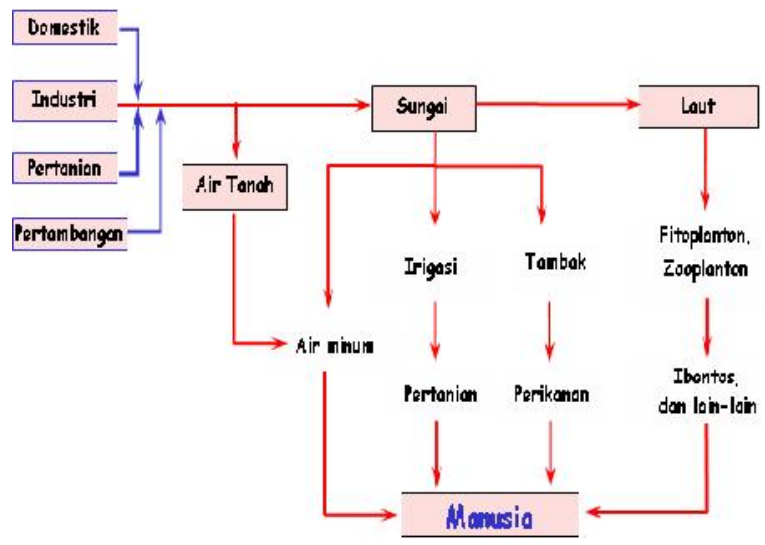

Gambar 10. : Diagram perjalanan polutan limbah sampai ke manusia.

\subsection{Baku Mutu Limbah Cair Industri Pengolahan Ikan}

Untuk menjaga kualitas lingkungan agar tidak terjadi pencemaran akibat pembuangan limbah cair dari kegiatan pengolahan ikan dan untuk memberikan dasar hukum pelaksanaan tugas bagi para pembina dan pengawas lingkungan, maka pemerintah telah mengeluarkan peraturan tentang baku mutu air limbah dari kegiatan ini. Secara lengkap isi peraturan tersebut dapat dilihat pada lampiran laporan ini, sedangan standar baku mutu kualitas limbahnya dapat dilihat seperti pada Tabel 11. s/d 13

\section{KESIMPULAN}

1. Dari hasil kajian diperoleh potensi jumlah limbah cair di Muncar mencapai 14.266 $\mathrm{m}^{3} /$ hari.

2. Sumber limbah dari kegiatan industri pengolahan ikan muncul sejak pengadaan bahan baku (pendaratan ikan), transportasi, proses produksi sampai teknik pengelolaan limbah yang kurang baik.

3. Sebagian besar industri pengolahan ikan di Muncar belum memiliki unit pengolahan yang memenuhi persyaratan dan membuang limbah cair secara langsung tanpa unit pengolahan.

4. Kualitas air limbah yang dibuang belum memenuhi baku mutu sehingga menimbulkan beberapa dampak negatif terhadap lingkungan di sekitar Muncar. 
5. Potensi timbulan limbah di Muncar sangat besar, sementara sarana yang tersedia untuk pengelolaan limbah sangat minim sekali baik di tingkat industri maupun di tingkat kawasan.

6. Pembuangan limbah industri di Muncar telah menyebabkan timbulnya berbagai dampak pencemaran terhadap lingkungan di sekitarnya.

7. Berbagai dampak pencemaran limbah di Muncar terjadi di berbagai sektor, antara lain terhadap estetika lingkungan, kondisi sosial ekonomi masyarakat, kualitas air permukaan, dan terhadap biota air di sepanjang jalur pembuangan limbah.

8. Lokasi industri yang menyebar di seluruh kawasan Muncar menyebabkan limbah yang timbul juga menyebar di seluruh kawasan industri dan menyebabkan semakin sulitnya melakukan pengelolaan limbah di kawasan ini.

9. Masalah pencemaran lingkungan di Muncar merupakan masalah bersama antara pengusaha, masyarakat dan Pemda. Sehingga untuk mengatasinya harus dilakukan secara bersama.

\section{DAFTAR PUSTAKA}

1. Adriaens, P., Kohler, HP.E, Kohler-Staub, D., and Focht, D.D. (1989). Bacterial dehalogenation of Chlorobenzoates and coculture biodegradation of 4,4dichlorobiphenyl. Appl. Environ. Microbiol. 5:887-892.

2. Chaney, R.L. 1980. Health Risks Assosiated with Toxic Metals in Minicipal Sludge, pp. 5973. In G. Bitton, B.L Risk of land Application. Proc. Ann Arbor Science Publisher, Inc. Michigan.

3. Overcash, M.R. (1981). Decomposition of Toxic and Nontoxic Organic Compounds in Soils. Ann Arbor Science Publishers Inc./The Butterworth Group, Michigan USA.

4. Kedeputian Bidang Pengendalian Pencemaran Lingkungan, KLH, "Laporan Akhir Pengelolaan Lingkungan Industri Pengolahan Ikan di Muncar, Banyuwangi," tahun 2007.

5. Raka, I G., Zen, M.T., Soemarwoto, O., Djajadiningrat, S.T., and Saidi, Z. (1999). Paradigma Produksi Bersih: mendamaikan pembangunan ekonomi dan pelestarian lingkungan. Penerbit Nuansa, Bandung, Indonesia

6. Suffet, I.H. (1977). Fate of Pollutants in the Air and Water Environments. Volume 8, Part 1, "Mechanism of interaction between environments and mathematical modeling and the physical fate of pollutants. Advances in Environmental Science and Technology. John Wiley \& Sons, A Wiley-Interscience Publications, New York, USA.

7. ------ (1977). Fate of Pollutants in the Air and Water Environments. Volume 8. Part 2, "Chemical and biological fate of pollutants in the environment". Advances in Environmnetal Science and Technology. John Wiley \& Sons, A Wiley-Interscience Publications, New York, . 


\section{LAMPIRAN}

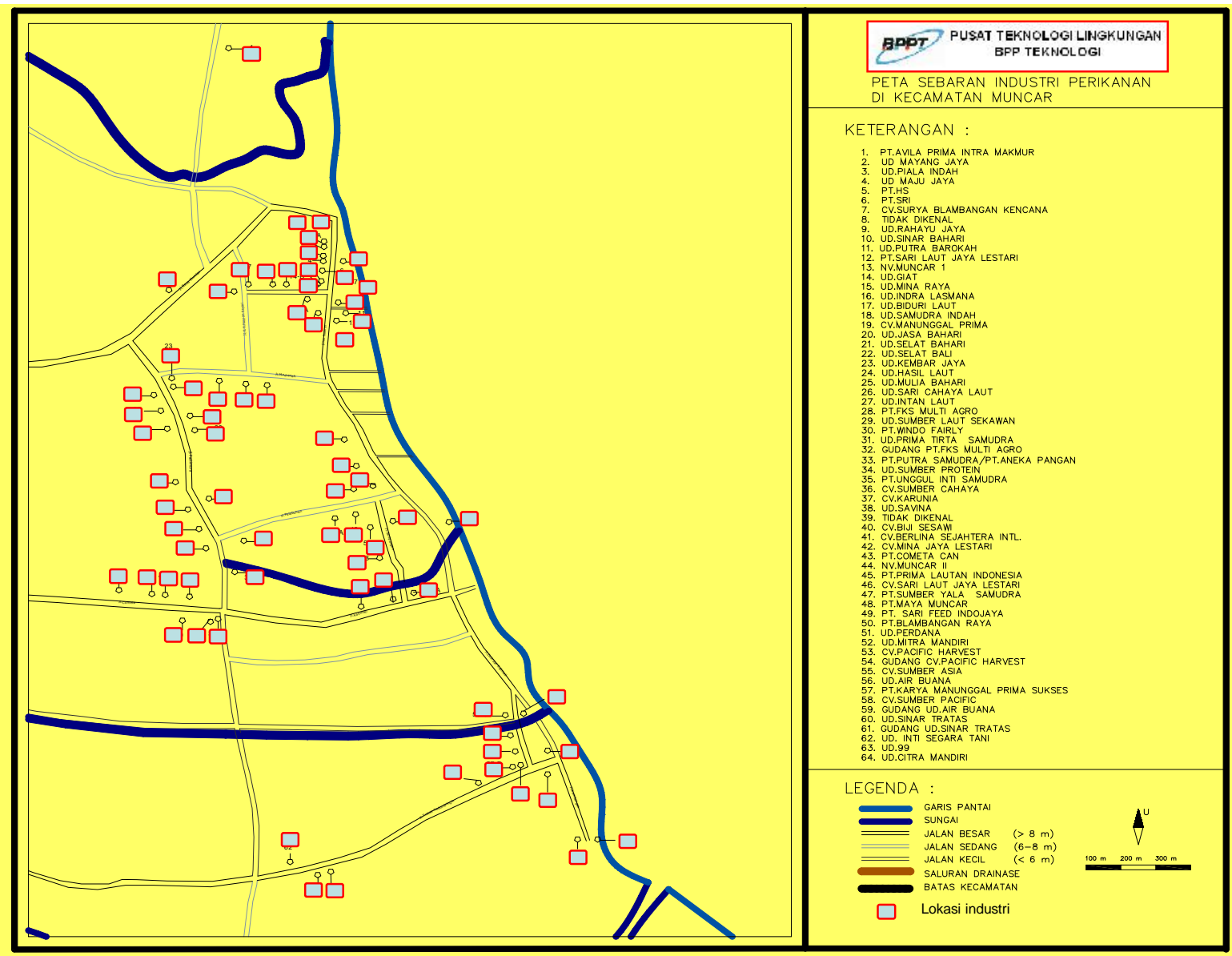

Gambar 1 : Peta Sebaran Industri Pengolahan Ikan di Mancar

Tabel 10. : Baku Mutu Air Limbah Bagi Usaha dan/atau Kegiatan Pengolahan Hasil Perikanan Yang Melakukan Lebih Dari Satu Jenis Kegiatan Pengolahan

\begin{tabular}{|l|c|c|}
\hline Parameter & Satuan & Kadar \\
\hline $\mathrm{pH}$ & - & $6-9$ \\
\hline TSS & $\mathrm{Mg} / \mathrm{l}$ & 100 \\
\hline Sulfida & $\mathrm{Mg} / \mathrm{l}$ & 1 \\
\hline Amonia & $\mathrm{Mg} / \mathrm{l}$ & 5 \\
\hline $\begin{array}{l}\text { Khlor } \\
\text { Bebas }\end{array}$ & $\mathrm{Mg} / \mathrm{l}$ & 1 \\
\hline BOD & $\mathrm{Mg} / \mathrm{l}$ & 100 \\
\hline COD & $\mathrm{Mg} / \mathrm{l}$ & 200 \\
\hline $\begin{array}{l}\text { Minyak- } \\
\text { Lemak }\end{array}$ & $\mathrm{Mg} / \mathrm{l}$ & 15 \\
\hline
\end{tabular}


Tabel 11. : Baku Mutu Air Limbah Bagi Kawasan Industri Perikanan Yang Melakukan Pengolahan Air Limbah Secara Terpusat

\begin{tabular}{|l|l|l|}
\hline Parameter & Satuan & Kadar \\
\hline $\mathrm{pH}$ & - & $6-9$ \\
\hline TSS & $\mathrm{Mg} / \mathrm{l}$ & 100 \\
\hline Sulfida & $\mathrm{Mg} / \mathrm{l}$ & 1 \\
\hline Amonia & $\mathrm{Mg} / \mathrm{l}$ & 5 \\
\hline Khlor Bebas & $\mathrm{Mg} / \mathrm{l}$ & 1 \\
\hline BOD & $\mathrm{Mg} / \mathrm{l}$ & 100 \\
\hline COD & $\mathrm{Mg} / \mathrm{l}$ & 200 \\
\hline Minyak-Lemak & $\mathrm{Mg} / \mathrm{l}$ & 15 \\
\hline
\end{tabular}

Sumber :

Peraturan Kementrian LH: No. 06 tahun 2007, tentang "Baku Mutu Air Limbah Bagi Usaha dan/atau Kegiatan Pengolahan Hasil Perikanan".

Tabel 12 : Baku Mutu Air Limbah Usaha dan/atau Kegiatan Pengolahan Hasil Perikanan Yang Melakukan Satu Jenis Kegiatan Pengolahan

\begin{tabular}{|c|c|c|c|c|c|c|c|c|c|c|}
\hline \multirow{3}{*}{ Parameter } & \multicolumn{4}{|c|}{ Kegiatan Pembekuan } & \multicolumn{4}{|c|}{ Kegiatan Pengalengan } & \multicolumn{2}{|c|}{$\begin{array}{l}\text { Pembuatan } \\
\text { Tepung Ikan }\end{array}$} \\
\hline & \multirow[t]{2}{*}{$\begin{array}{l}\text { Kadar } \\
\text { (mg/L) }\end{array}$} & \multicolumn{3}{|c|}{$\begin{array}{l}\text { Beban Pencemaran } \\
\text { (kg/ton) }\end{array}$} & \multirow[t]{2}{*}{$\begin{array}{l}\text { Kadar } \\
\text { (mg/L) }\end{array}$} & \multicolumn{3}{|c|}{$\begin{array}{l}\text { Beban Pencemaran } \\
\text { (kg/ton) }\end{array}$} & \multirow{2}{*}{$\begin{array}{l}\text { Kadar } \\
\text { (mg/L) }\end{array}$} & \multirow{2}{*}{$\begin{array}{l}\text { Beban } \\
\text { cemaran } \\
\text { (kg/ton) }\end{array}$} \\
\hline & & Ikan & Udang & Lain-lain & & Ikan & Udang & Lain-lain & & \\
\hline pH & \multicolumn{10}{|l|}{$6-9$} \\
\hline TSS & 100 & 1 & 3 & 1,5 & 100 & 1,5 & 3 & 2 & 100 & 1,2 \\
\hline Sulfida & - & & - & - & 1 & 0,015 & 0,03 & 0,02 & 1 & 0,012 \\
\hline Amonia & 10 & 0,1 & 0,3 & 0,15 & 5 & 0,075 & 0,15 & 0,1 & 5 & 0,06 \\
\hline $\begin{array}{l}\text { Khlor } \\
\text { Bebas }\end{array}$ & 1 & 0,01 & 0,03 & 0,015 & 1 & 0,015 & 0,03 & 0,02 & - & - \\
\hline BOD & 100 & 1 & 3 & 1,5 & 75 & 1,125 & 2,25 & 1,5 & 100 & 1,2 \\
\hline COD & 200 & 2 & 6 & 3 & 150 & 2,25 & 4,5 & 3 & 300 & 3,6 \\
\hline $\begin{array}{l}\text { Minyak- } \\
\text { Lemak }\end{array}$ & 15 & 0,15 & 0,45 & 0,225 & 15 & 0,225 & 0,45 & 0,3 & 15 & 0,18 \\
\hline $\begin{array}{l}\text { Kuantitas } \\
\text { Air } \\
\text { Limbah } \\
\text { (m³/ton) }\end{array}$ & & 10 & 30 & 15 & & 15 & 30 & 20 & & 12 \\
\hline
\end{tabular}


Kawasan Muncar merupakan daerah penghasil ikan dan industri pengolahan hasil ikan skala industri besar, industri kecil maupun skala rumah tangga. Produksi pengolahan ikan dari industri-industri tersebut saat ini rata-rata mencapai sekitar 1.300 ton perhari. Besarnya volume kegiatan pengolahan ikan di Muncar ini telah menimbulkan pencemaran terhadap lingkungan, terutama terhadap pencemaran air, udara dan tanah. Sumber pencemaran yang ditimbulkan oleh industri pengolahan ikan berasal dari beberapa sumber mulai dari transportasi bahan baku, pemindahan bahan baku, pencucian bahan, kegiatan quality control, sampai kepada aktivitas karyawan (limbah domestik) serta lainnya. Saat ini proses pengelolaan limbah masih sangat minim ditambah rendahnya tingkat pemahaman Instalasi Pengolahan Air Limbah (IPAL) dan sistem manajemen limbah yang ada, sehingga hampir semua limbah yang dihasilkan di wilayah ini langsung dibuang ke saluran umum. Pembuangan limbah secara langsung tanpa pengolahan ini menyebabkan tingginya tingkat pencemaran lingkungan di sekitar lokasi industri. Untuk mengetahui dampak pencemaran yang timbul maka dalam tulisan ini akan dijelaskan tentang seberapa besar potensi pencemaran limbah cair, jenis dan karakteristik limbah industri pengolahan ikan dan melakukan evaluasi pengelolaan limbah industri pengolahan ikan di Muncar, serta jenis dampak pencemaran akibat pembuangan limbah industri pengolahan ikan di Muncar. 